\title{
ANALYSIS OF GEOGRAPHICALLY WEIGHTED REGRESSION (GWR) ON RETAIL PRICES OF MEDIUM RICE AND RED CHILI IN JAVA
}

\section{Jan Piter Sinaga ${ }^{*}$, , Agung Hendriadi ${ }^{*}$, Muhammad Firdaus ${ }^{* *}$, Akhmad Fauzi $^{* *}$, Idha Widi Arsanti***)}

*Food Security Agency, Ministry of Agriculture Republic of Indonesia Jl. Harsono RM No.3 Ragunan 12560, Pasar Minggu, South Jakarta, Indonesia ${ }^{* *}$ Department of Economics, Faculty of Economics and Management, IPB University Jl. Kamper Wing 4 Level 5 Kampus IPB Dramaga 16680 Bogor, Indonesia ${ }^{* * *}$ BPPSDMP, Ministry of Agriculture Republic of Indonesia Jl. Harsono RM No.3 Ragunan 12560, Pasar Minggu, South Jakarta, Indonesia

\begin{abstract}
Research using a global regression model might not be appropriate to find out the factors that influence strategic food prices based on spatial characteristics. To analyze the spatial effect, Geographically Weighted Regression (GWR) was employed. GWR models are better than OLS, which is indicated by the higher R2 GWR and lower AIC values. The GWR analysis provides the following findings: (1) the wholesale price most influential on the retail price of medium rice and red chili both during the main harvest and non-harvest periods; (2) the harvest pattern results in the effect of production and producer prices on the retail prices of the major harvest and non-harvest periods. Management of inter-regional distribution must be carried out to maintain supply stability and disparity in food prices between regions; (3) producer prices are integrated with trader prices in the district of production centers and surrounding areas while the integration of food prices at the consumer level occurs in the main economic center area of the region. These aspects have different effects for each region and district because the estimated parameters can be positive or negative. Testing during the harvest season (April) and non-harvest can also produce estimates that vary according to the specific characteristics of each location.
\end{abstract}

Keywords: spatial analysis, Geographically Weighted Regression (GWR), retail prices, wholesale price, spatial distribution patterns

\begin{abstract}
Abstrak: Penelitian dengan model regresi global mungkin tidak tepat untuk mengetahui faktor-faktor yang mempengaruhi harga pangan strategis berdasarkan karakteristik spasial. Untuk menganalisis efek spasial, digunakan Geographically Weighted Regression (GWR). Model GWR lebih baik daripada OLS. yang ditunjukkan dengan nilai R2 GWR lebih besar dan nilai AIC yang lebih kecil daripada analisis OLS. Analisis GWR memberikan temuan sebagai berikut: (1) harga grosir paling berpengaruh terhadap harga eceran beras medium dan cabai merah baik pada saat panen raya maupun non panen; (2) pola panen mengakibatkan pengaruh produksi dan harga produsen terhadap harga eceran periode panen raya dan non panen. Pengelolaan distribusi antar wilayah harus dilakukan untuk menjaga stabilitas pasokan dan disparitas harga pangan antar wilayah; (3) harga produsen terintegrasi dengan harga pedagang di wilayah sentra produksi dan sekitarnya sedangkan integrasi harga pangan di tingkat konsumen terjadi di wilayah sentra ekonomi utama wilayah tersebut. Aspek-aspek tersebut memiliki pengaruh yang berbeda untuk setiap wilayah dan kabupaten karena parameter yang diestimasi bisa positif atau negatif. Pengujian selama musim panen (April) dan nonpanen juga dapat menghasilkan perkiraan yang bervariasi sesuai dengan karakteristik spesifik masing-masing lokasi.
\end{abstract}

Kata kunci: analisis spasial, Geographically Weighted Regression (GWR), harga eceran, harga grosir, pola sebaran spasial

\footnotetext{
${ }^{1}$ Corresponding author:

Email: dustindavinsinaga@gmail.com
} 


\section{INTRODUCTION}

Production disparities between time and region, natural disasters, distribution, storage, and limited information are the main factors causing price fluctuations (Udoh and Sunday, 2007). Distribution from surplus areas to deficit areas will be efficient if the costs of the trading system occurred are still profitable for producers and consumers (Adenegan, 2012). If the transfer fee is less than the price difference between the two markets, the market is efficient (Negassa et al. 2003). Therefore, controlling disparities and high price fluctuations of strategic food prices must be carried out by the government through a more effective and efficient interregional trade process. Inter-regional trade relations are crucial to ensure food availability in all regions, especially in consumer areas.

The relationship of market prices that are geographically separated can be analyzed with the concept of spatial market integration using the spatial equilibrium model. Barrett and Li (2002) defined market integration as the ability to sell products between markets where demand, supply, and transaction costs in different markets determine prices and trade flows simultaneously and transmitting price shocks. According to Sonogo and Amadou (2010), market integration is the flow of goods and information, prices, distances, shapes, and times or defined as trade relations between markets in the process of forming and transmitting prices from market to market.

Integration between markets is highly dependent on the diversity of specific factors possessed by each region. Analysis of the factor influencing integration and food prices mostly use cointegration analysis (Engle and Granger, 1987; Goodwin and Schroeder, 1991; Negassa et al. 2003; Firdaus and Gunawan, 2012), as well as global regression analysis (Hidayanto, 2014; Aditya, 2016). Regression analysis is an analytical method that can be used to analyze data and determine the independent variables that have a relationship with the response variables. The assumptions in linear regression are residual normality, homogeneity of variance, and residual freedom. However, problems often arise when the assumption of residual freedom is violated, and spatial effects cause the homogeneity of residual variance.

Spatial effects cause spatial diversity in price formation in each region. Spatial data analysis is an analysis related to the influence of location. This is based on the first law of geography put forward by Tobler in Bekti (2012), which states that everything is related to one another, but something close together has more connection. In spatial data, the observations in one location often depend on neighbourhood location. The spatial approach does not relate only to distance, location and situation, access, correlation, and pattern (Muta'ali, 2012) and the spatial pattern, correlation between variables, and spatial process. Moreover, spatial econometrics correlates with regional and rural economies based on biological and geological phenomenon and regional science (Anselin, 1988). Therefore, an analysis using the geographical disaggregation technique at the lowest governmental structure is needed to replace the macro approach for analysis integration and food prices in Indonesia.

The occurrence of spatial dependence and spatial diversity on price formation in each region can be overcome by Geographically Weighted Regression (GWR). GWR can be used as a tool to explore spatial variations in the relationship between dependent and independent variables to produce visualization and a locally set of regression (Pravitasari et al. 2015). Therefore, this study aimed to analyze the influence of spatial aspects on strategic food prices in Indonesia and formulate the implementation of strategic food supply and price stabilization policies in Indonesia.

The global and spatial approaches were compared, and the most factors influencing prices were suggested. The factors that influence retail prices in this study are based on research by Ridhwan et al. (2012) and Hidayanto (2014) that is wholesale prices, producer prices, production, consumption, GDP Regional (PDRB), and marketing margin (MPP). The modelling of the factors that affect the retail price of medium rice and red chili uses a district/city basis. This research aims to capture the influence of the factors that affect the retail price of medium and large red chilies in the Java region.

\section{METHODS}

The data used in this study were the cross-section data (April 2018 and December 2018) from 111 districts/ cities in the Java region for medium rice analysis and the cross-section data (April 2018 and September 2018) from 100 districts/cities in Java for red chili analysis. The districts/cities data that are used as research samples 
are data on retail prices, wholesale and retail prices for districts/cities in the Food Price Panel conducted by the Food Security Agency, Ministry of Agriculture.

The independent variables used to analyze the factors that influence retail price were wholesale prices, producer price, production, consumption, regional GDP (PDRB), margin marketing (MPP) while the independent variable was the retail price. Annual consumption data such as PDRB and MPP are used in the analysis of medium rice in April and December and red chili in April and September. These factors are analyzed through stages spatial dependency test, spatial heterogeneity test, GWR Model analysis, comparison of OLS and GWR test, significance test and GWR model interpretation, and mapping (Figure 1).

Global regression analysis (Hill et al. 2011; Gujarati, 2010) and Geographically Weighted Regression (GWR) aim to analyze the factors that affect retail prices. The GWR model is a weighted global regression model (Fotheringham et al. 2002, Fischer and Getis, 2010). In this model, model parameters are estimated for each geographic coordinate, so that each coordinate has a different estimated regression parameter. Compared to OLS or global regression analysis, the GWR model is reported to be more suitable for data description (Ali et al. 2007). This is the research hypothesis that GWR is thought to be better than OLS with wholesale, production, and producer prices being the most influential factors with different magnitudes of influence for each location. The general form of GWR is:

$$
y_{i}=\beta_{0}+\sum_{\mathrm{k}=1}^{\mathrm{n}} \beta_{k} x_{i k}+\varepsilon_{i}
$$

Where yi is the dependent variable at $\mathrm{i}$ location $(\mathrm{i}=1,2, \ldots, \mathrm{n})$, xik is independent variable $\mathrm{k}$ at $\mathrm{i}$ location (Table 1), $\beta$ is the regression coefficient and $i$ is the error assumed as identical, independent, and has normal distribution with constant variance $(\alpha 2)$. The assumption was tested by the Kolmogorov Smirnov method for normal distribution, the Glejser method for identical, and the Durbin Watson method for independent. The parameters were estimated using the Ordinary Least Square (OLS) method. The GWR model is (2).

$$
y_{i}=\beta_{0}\left(u_{i}, v_{i}\right)+\sum_{\mathrm{k}=1}^{\mathrm{n}} \beta_{k}\left(u_{i}, v_{i}\right) x_{i k}+\varepsilon_{i}
$$

Where yi is the dependent variable at $\mathrm{i}$ location $(i=1,2, . ., n), \beta 0$ is the regression coefficient, (ui,vi) are the longitude and latitude coordinates at $\mathrm{i}$ location in the certain geographical region, $\beta \mathrm{k}$ is the regression coefficient $\mathrm{k}$ in each region or the manifestation of the continuous function of $\beta \mathrm{k}$ (ui, vi) at i location, xik is independent variable $\mathrm{k}$ at $\mathrm{i}$ location, and $\varepsilon i$ is the error assumed as identical, independent and has a normal distribution with constant variance ( $\alpha 2)$. The parameters $\beta$ were estimated by Weighted Least Square (WLS) (Equation 2).

$$
\beta^{\wedge}(\mathrm{i})=(\mathrm{XTW}(\mathrm{i}) \mathrm{X})-1 \mathrm{XTW}(\mathrm{i}) \mathrm{y}
$$

where $\mathrm{X}$ is the data matrix of independent variables, $\mathrm{y}$ is the vector dependent variable, and $\mathrm{W}(\mathrm{i})$ is the weighting matrix. At this stage, the identification of the GWR model used is as follows :

$$
\begin{aligned}
& \mathrm{Y}=\beta_{0}\left(\mathrm{u}_{\mathrm{i}}, \mathrm{v}_{\mathrm{i}}\right)+\beta_{1}\left(\mathrm{u}_{\mathrm{i}}, \mathrm{v}_{\mathrm{i}}\right) \mathrm{X}_{1}+\beta_{2}\left(\mathrm{u}_{\mathrm{i}}, \mathrm{v}_{\mathrm{i}}\right) \mathrm{X}_{2}+\ldots+\beta_{5}\left(\mathrm{u}_{\mathrm{i}}, \mathrm{v}_{\mathrm{i}}\right) \\
& \mathrm{X}_{5}+\varepsilon
\end{aligned}
$$

Where $\mathrm{Y}$ is the dependent variable, $\mathrm{Xn}$ is the independent variable, $\beta \mathrm{n}$ is the regression coefficient, and $\varepsilon$ is the residual. Each location has a different parameter value or regression coefficient. GWR requires a weighted matrix that shows neighbors between locations. The weighting matrix type is the bi-square kernel (Equation $4)$.

$$
w_{j}\left(u_{i}, v_{i}\right)=\left\{\begin{array}{l}
{\left[1-\left(\frac{d_{i j}}{b_{i(q)}}\right)^{2}\right]^{2}, \text { if } d_{i j}<b} \\
0, \text { if } d_{i j}>b
\end{array}\right.
$$

Where wj is the weighted among location $\mathrm{i}$ in coordinate ui,vi, and other location, dij is Euclidean distance $i$ and $\mathrm{j}$ location, and $\mathrm{b}$ is bandwidth. Bandwidth is measured by the distance weighting function and the extent of influence on the location to another location. Bandwidth is calculated based on cross-validation in Equation 5.

$$
C V=\sum_{i=1}^{n}\left[y_{i}-\hat{y}_{i \neq 1}(b)\right]^{2}
$$

Where $\left[y_{i}-\hat{y}_{i \neq 1}(b)\right]$ is predicted to be valued from the model without observation i. Identification of spatial effect is also important to know that the data is more relevant to analyzed by spatial model, especially for GWR. The methods used for identification amongst others were Moran's test, Local Indicator of Spatial Autocorrelation (LISA) to test the spatial independence, 
and Breusch Pagan's test for spatial heterogeneity. Moran and LISA tests were used to determine whether there is a spatial dependency among locations. The null hypothesis for both tests were no spatial dependencies. On the other hand, Breusch Pagan uses the null hypothesis that there is no spatial heterogeneity in the model. The models were run using $\mathrm{R}$ Software with sugar and spdep packages.

\section{RESULTS}

Medium retail rice prices in April at low price levels in Pandeglang, Lebak, and Serang which together with districts/cities of rice production centers in West Java such as Bogor, Cianjur, Purwakarta, Bekasi, and Kerawang form a low retail price cluster. The high price quadrant is located in Cilegon City, Tangerang Regency, South Tangerang City, Serang City, and DKI Jakarta Province forming the high price quadrant. The same pattern occurred in Subang, Indramayu, Sumedang, Bandung, Garut, Tasikmalaya, Tasikmalaya City, Kuningan, and Ciamis. Random patterns also occur in districts/cities in Central Java and East Java in April and December (Figure 2).

Meanwhile, the distribution pattern of red chili prices is more clustered and has similar characteristics in adjacent locations. There are two Java clusters, namely West Java and East Java. The western Java sub-cluster tends to high price patterns consisting of West Java, Banten, DKI Jakarta. Although West Java's red chili production had a surplus of 7,141 tons in April, the supply to the Keramatjati Main Market (PIKJ) made the price of red chili in this cluster at a high price level.

The decline in production at the non-harvest season will further exacerbate the price spike at a higher level. The eastern Java cluster consists of Central Java and East Java with a tendency for low-low price distribution patterns. Central Java and East Java are centers of red chili production. This cluster surplus of 3,924 tons resulted in supply being able to hold prices at a relatively lower level. Even during the non-harvest period in September, supply and demand were still relatively balanced.

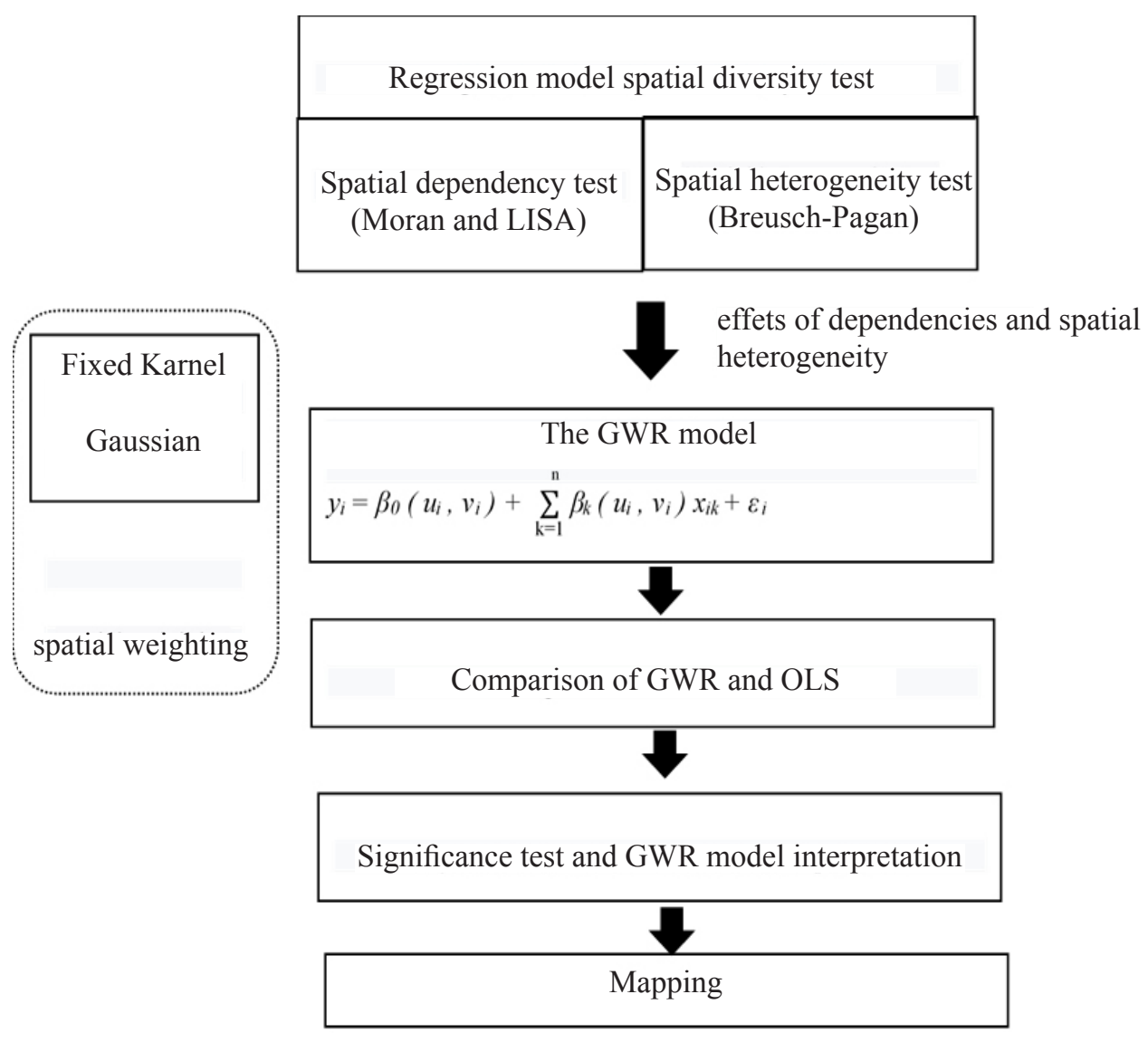

Figure 1. Research model 


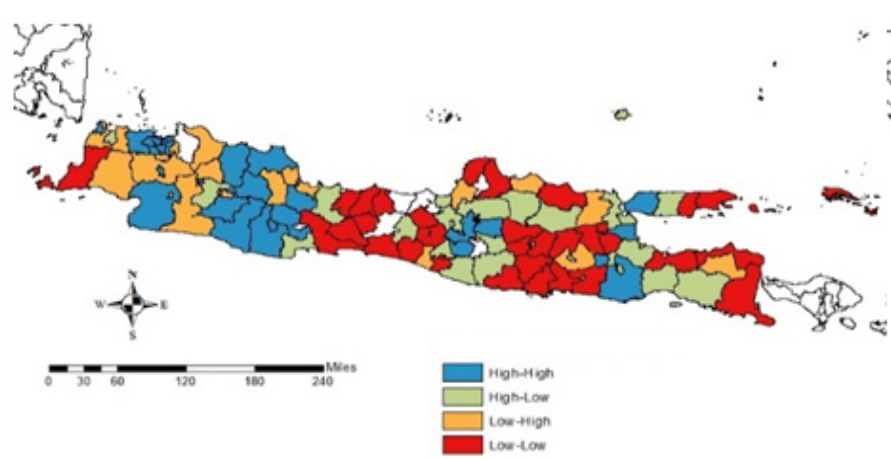

(a)

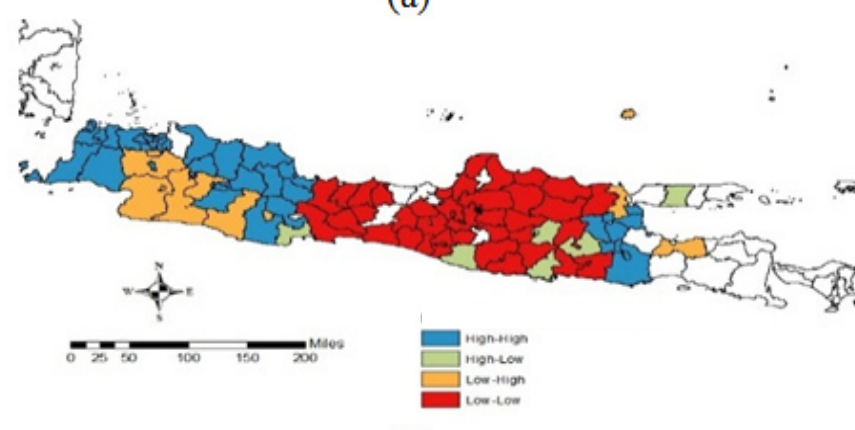

(c)

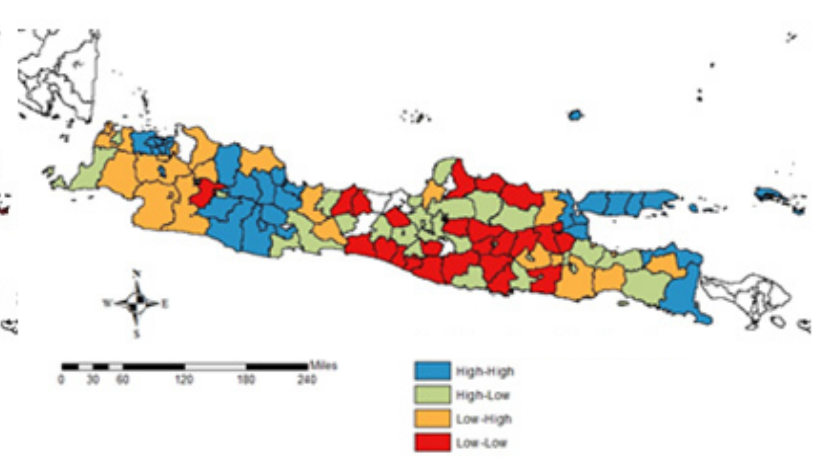

(b)

Figure 2. The distribution pattern of the price of medium rice (a) April, (b) December and Red chili in Java (c) April, (d) September.

The result of the global regression model (OLS) is presented in Table 1. The global regression model assumed that the parameters for all districts/cities are similar, indicating that the factors influencing retail price in all districts/citis were also similar. The regression coefficient in Table 1 was used in the global regression model in equation 1 . The resulting model indicated that retail medium rice prices had a positive correlation with wholesale prices in both April and December but other factors such as production, producer prices, and consumption have different effects in April and December. The same thing happened to the red chili model where retail red chili prices had a positive correlation with wholesale prices and consumption both April and December while production dan producer prices have different effects in April and December.

Further residual analysis using the Kolmogorov Smirnov, Durbin Watson test, and the Glejser method showed that the assumption of normal distribution and the assumption on the similarity of the retail price in all regions/cities were not met. Therefore, the use of spatial modeling approach, such as Geographically Weighted Regression, is considered. Before the spatial analysis approach was applied, the dependency analysis using the Moran test and Local Indicator of Spatial Autocorrelation (LISA) and spatial heterogeneity using the Breusch-Pagan test was used to observe the spatial effect on medium rice and red chili retail prices. The analysis results are shown in Table 2.

The spatial heterogeneity analysis was used to determine the spatial effect and the characteristic heterogeneity among districts/cities. Using the Breusch Pagan test, spatial heterogeneity was found when the global regression model (Equation 1 and Table 1) was used. Also, the test of the residual assumption found the residual heterogeneity. Because spatial dependency and heterogeneity effects were reported from those analyses, the use of the Geographically Weighted Regression (GWR) model in equation 2 is recommended. The result of the GWR model is presented in Table 2. This model used a fixed kernel gaussian for the weighting process and a bandwidth value of 8.58401 (April) and 4.041733 (December) for medium rice model 7.535962 (April) and 5.848539 (September) for the red chili model. This shows that the correlation of a district/ city is closer to other regions/cities in the non-harvest period. The estimated parameters of the GWR model for each region/city are shown in Figure 3-7. 
Table 1. The Comparison of GWR and Global regression model

\begin{tabular}{|c|c|c|c|c|c|c|c|c|c|c|c|c|}
\hline & \multicolumn{6}{|c|}{ Medium Rice Java } & \multicolumn{6}{|c|}{ Red Chilli Java } \\
\hline & \multicolumn{3}{|c|}{ April 2018} & \multicolumn{3}{|c|}{ December 2018} & \multicolumn{3}{|c|}{ April 2018} & \multicolumn{3}{|c|}{ December 2018} \\
\hline & \multirow[t]{2}{*}{ OLS } & \multicolumn{2}{|c|}{ GWR } & \multirow[t]{2}{*}{ OLS } & \multicolumn{2}{|c|}{ GWR } & \multirow[t]{2}{*}{ OLS } & \multicolumn{2}{|c|}{ GWR } & \multirow[t]{2}{*}{ OLS } & \multicolumn{2}{|c|}{ GWR } \\
\hline & & Median & Max & & Median & Max & & Median & Max & & Median & Max \\
\hline Intersept & 2530 & 2541 & 2611 & 1782 & 1699 & 2.138 & 8649 & 8671 & 8985 & 944 & 1240 & 1645 \\
\hline $\begin{array}{l}\text { Wholesale } \\
\text { Proce }\end{array}$ & 0,8534 & 0,8513 & 0,8567 & 0,8532 & 0,8715 & 0,9044 & 0,8949 & 0,8918 & 0,8933 & 0,9229 & 0,9110 & 0,9137 \\
\hline $\begin{array}{l}\text { Producer } \\
\text { price }\end{array}$ & $-0,1530$ & $-0,1498$ & $-0,1459$ & 0,0269 & 0,0078 & 0,0404 & $-0,1852$ & $-0,1849$ & $-0,1794$ & 0,0944 & 0,0808 & 0,0918 \\
\hline Production & $-0,0026$ & $-0,0026$ & $-0,0024$ & 0,0053 & 0,0051 & 0,0092 & $-0,0054$ & $-0,0058$ & $-0,0055$ & $-0,0209$ & $-0,0256$ & $-0,0129$ \\
\hline Consumption & 0,0094 & 0,0094 & 0,0099 & $-0,0017$ & $-0,0014$ & 0,0023 & 0,8655 & 0,8913 & 0,9358 & 1,4100 & 1,8309 & 2,1878 \\
\hline $\begin{array}{l}\text { Regional } \\
\text { GDP (PDRB) }\end{array}$ & & & & 0,00053 & 0,00050 & 0,0007 & & & & $-0,0028$ & $-0,00351$ & $-0,0015$ \\
\hline $\mathrm{R} 2$ & 0,8091 & \multicolumn{2}{|c|}{0,8103} & 0,6675 & \multicolumn{2}{|c|}{0,6981} & 0,8599 & \multicolumn{2}{|c|}{0,8609} & 0,9074 & \multicolumn{2}{|c|}{0,9120} \\
\hline AIC & 1.642 & \multicolumn{2}{|c|}{1.633} & 1642,6 & \multicolumn{2}{|c|}{1631,1} & 1818 & \multicolumn{2}{|c|}{1810} & 1785 & \multicolumn{2}{|c|}{1772} \\
\hline $\begin{array}{l}\text { Number of } \\
\text { Parameters }\end{array}$ & 7 & \multicolumn{2}{|c|}{777} & 7 & \multicolumn{2}{|c|}{777} & 6 & \multicolumn{2}{|c|}{600} & 6 & \multicolumn{2}{|c|}{600} \\
\hline Sigma & 371 & \multirow{2}{*}{\multicolumn{2}{|c|}{14874584}} & 371 & \multirow{2}{*}{\multicolumn{2}{|c|}{14431532}} & 2025 & \multirow{2}{*}{\multicolumn{2}{|c|}{398929672}} & 1696 & \multirow{2}{*}{\multicolumn{2}{|c|}{267748477}} \\
\hline $\begin{array}{l}\text { Residual Sum } \\
\text { of Square }\end{array}$ & 14963804 & & & 15028385 & & & 401719886 & & & $2,8 \mathrm{E}+08$ & & \\
\hline
\end{tabular}

Table 2. GWR parameter estimation results

\begin{tabular}{lcccc}
\hline & \multicolumn{2}{c}{ Rice } & \multicolumn{2}{c}{ Red Chili } \\
\cline { 2 - 5 } & Median & Median & Median & Median \\
\cline { 2 - 5 } & April 2018 & December 2018 & April 2018 & September 2018 \\
\hline Intercept & 2.541 & 1.699 & 8.671 & 1.240 \\
Wholesale price & $0,8514^{* * *}$ & $0,8715^{* * *}$ & $0,8918^{* * *}$ & $0,9110^{* * *}$ \\
Producer price & $-0,1498$ & 0,0078 & $-0,1849^{*}$ & 0,0808 \\
Production & $-0,0026^{* *}$ & 0,0051 & $-0,0058^{* *}$ & $-0,0256$ \\
Consumption & $0,0094^{* * *}$ & $-0,0014^{* * *}$ & 0,8913 & 1,8309 \\
Regional GDP & & $0,00050^{*}$ & & $-0,0035$ \\
Marketing Margin & 3,0490 & & $69,169^{* *}$ & $37,8690^{*}$ \\
\hline
\end{tabular}

Note: ${ }^{* * *}$ ) significant at the $1 \%$ level; ${ }^{* *}$ ) significant at the $5 \%$ level; ${ }^{*}$ ) significant at the $10 \%$ level

Wholesale price is the most significant factor influencing the retail price of medium rice and red chili in each analysis. When other factors are constant the retail price of medium rice will increase by 0.8514 percent (April) and 0.8715 percent (December) due to the increase in wholesale price by the factor of 1 , respectively. Likewise, the retail price of red chili will increase by 0.8918 percent (April) and 0.9110 percent (September). The retail price of medium rice is also significantly influenced by Bulog's consumption and distribution in April and December. Still, the consumption factor is not significant in the red chili analysis.

Production is an important factor in the food supply. Sufficient production(surplus) will maintain the stability of consumer prices because the amount of supply can meet the demand, especially during the harvest period. The retail price of medium rice will decrease by 0.0026 percent, while the retail price of red chili will decrease by 0.0058 percent due to the increase in production by the factor of 1 , respectively.

The results of the GWR analysis for each region/city show a different effect on each commodity and the time of analysis. The wholesale price coefficient value for April analysis starts from the largest in the western region (Banten, DKI Jakarta, and West Java) to the smallest in East Java. The coefficient value is greatest in DKI and Banten, namely $0.8545-0.8567$, followed by the wholesale price coefficient value for West Java 
of $0.8525-0.8545$ and Central Java of $0.8506-0.8525$. The coefficient value of the wholesale price of East Java is $0.8466-0.8506$ is the smallest among other regions (Figure 3a).

December GWR results show the opposite. In this test, the wholesale price coefficients start from the smallest in the western region of Banten, DKI Jakarta, and West Java to the largest in East Java. The highest coefficient value is in DKI and Banten, which is 0.8109 -0.8282 , followed by the wholesale price coefficient for West Java of $0.8282-0.8494$ and Central Java of $0.8494-0.8697$. Furthermore, the value of the East Java wholesale price coefficient of $0.8697-0.9044$ is the largest among other regions. Rice production deficit in December where Banten, DKI, and West Java cluster deficits amounted to 419,975 tons (Figure 3b). According to Susilowati (2017), most of the supply from outside the region in this period came from South Sulawesi. Supplies from outside Java and Bulog's stock flows to traders, causing the wholesale price coefficient in this cluster to be lower than in the eastern cluster.
Rice production hurts the retail price of medium rice because of the large supply during the harvest period. Producer prices (GKP) decreased to the lowest price level, which pushed down the retail price of medium rice. The magnitude of the effect of production on the retail price of medium rice in all regencies/cities of Java Island for all regencies/cities is relatively similar. East Java has the largest parameter coefficient value -0.0026 to 0.0028 , while the parameter coefficient value for West Java is between -0.0023 and -0.0025 (Figure 4a).

In December, Java's rice production was in deficit, or a shortage of supply increased retail prices. Due to the shortage of supply in December, the retail price of medium rice remained high, so the production coefficient was positive for the Java retail price. In December, the rice production deficit caused the retail price of medium rice to increase, especially in the western part of Java and DKI Jakarta. The parameter coefficient values reached $0.0056-0.0092$ (Figure $4 b)$.

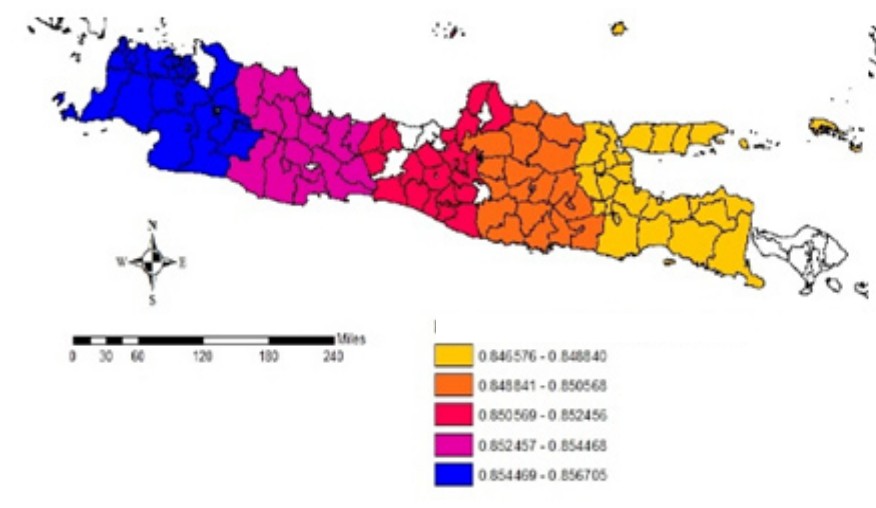

(a)

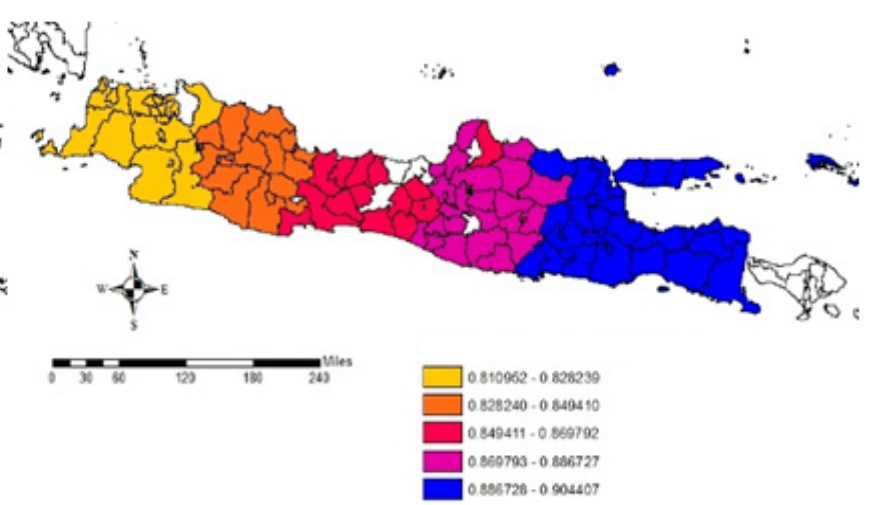

(b)

Figure 3. Parameter Estimates of medium rice GWR model: wholesale price (a) April, (b) December

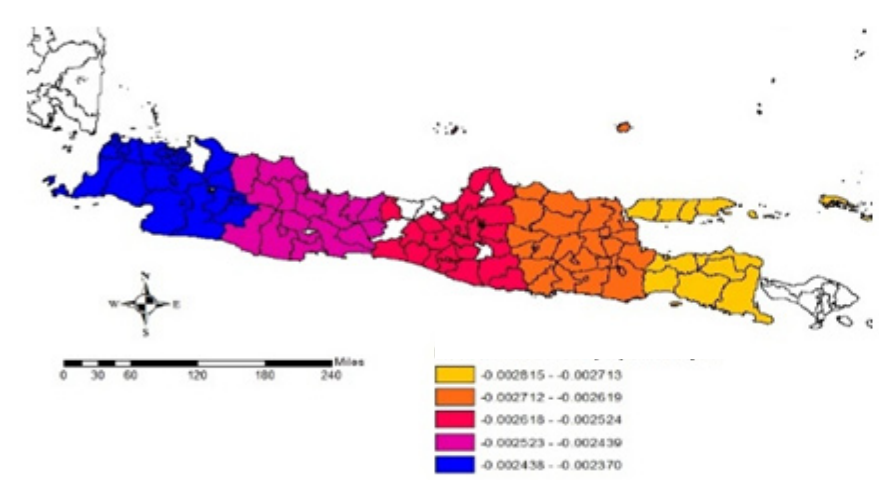

(a)

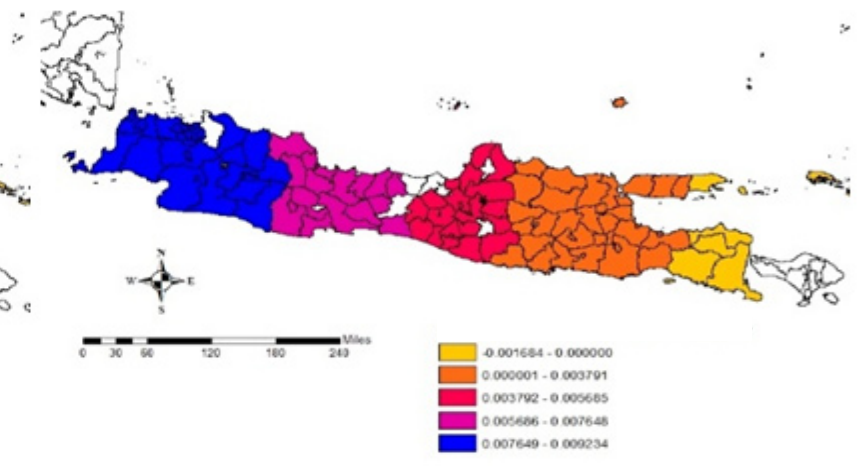

(b)

Figure 4. Parameter estimates of medium rice GWR model: production (a) April, (b) December 
The amount of demand (consumption) had a positive effect on retail prices. The smallest coefficient of rice consumption occurred in Banten and West Java at $0.0089-0.0091$, followed by Central Java at 0.0091 0.0093 , and the largest occurred in East Java at 0.0097 -0.0099 .

PDRB and MPP have a positive effect on the retail price of medium rice in Java. Rice supply flows to the center of economic growth in the western sub-cluster (DKI Jakarta and its surroundings). PDRB and MPP are more influential in DKI, Banten, and West Java than in the eastern Java cluster. Ridhwan et al (2012) suggested that people who have a higher income tend to consume rice at a higher price. The significant effect of MPP on the retail price of medium rice in Java indicates that distribution is smooth and efficient in Java). Similar observation was also reported from previous studies (Baquedano and Liefert, 2014; Varela et al. 2012; Siddique et al. 2008).

The Java MPP coefficient showed a significant effect at 5\% in April and 10\% in December. MPP coefficient value of rice of 3.3806 was much smaller than the coefficient of red chili of 41.1421. This condition highlighted the more advanced logistic infrastructure of rice as compared to red chili. Therefore, the effort to strengthen the logistics system of perishable commodities such as red chili should be supported by improving logistics and transportation infrastructures. Likewise, the strengthening of the food logistics system in regions outside Java, especially in Eastern Indonesia, should also be accompanied by the improvement of logistics and transportation infrastructures.
The wholesale price of red chili also significantly affected the increase in retail prices of Java rice at a level of 1\% in April and September. The wholesale price coefficient was relatively similar in all regions of Java in April. The April wholesale price coefficient value was $0.8911-0.8933$ (Figure 5a) and the September wholesale price coefficient value was $0.9082-0.9132$ (Figure $5 \mathrm{~b}$ ). The adjustment from wholesaler prices to retail prices was faster than the adjustment from producer prices to wholesaler prices (Holts and van Crommon-Taubadel, 2014). During the April harvest season, supply from farmers to wholesalers increased evenly so that the coefficient of wholesale prices was relatively similar to retail prices throughout Java. In September, when the harvest period decreases, the supply from farmers to large traders tends to decrease and is uneven, causing variation in the wholesale price coefficient. As a result, the disparity of retail prices among regions also tends to be higher.

The production of Javanese red chili shows a negative effect on the retail price of Javanese red chili. Production affects the amount of supply and results in a decrease in the retail price of red chili. These results are in line with Irawan (2007) and Elvina (2016) research, which state that the amount of supply harms consumer red chili prices. The interesting thing shown by the GWR test results for Java red chili is that the September production coefficient is greater than the April production coefficient. The April production coefficient is -0.0055 to -0.0058 (Figure 6a), while the September production coefficient is 0.0129 to -0.0324 (Figure 6b).

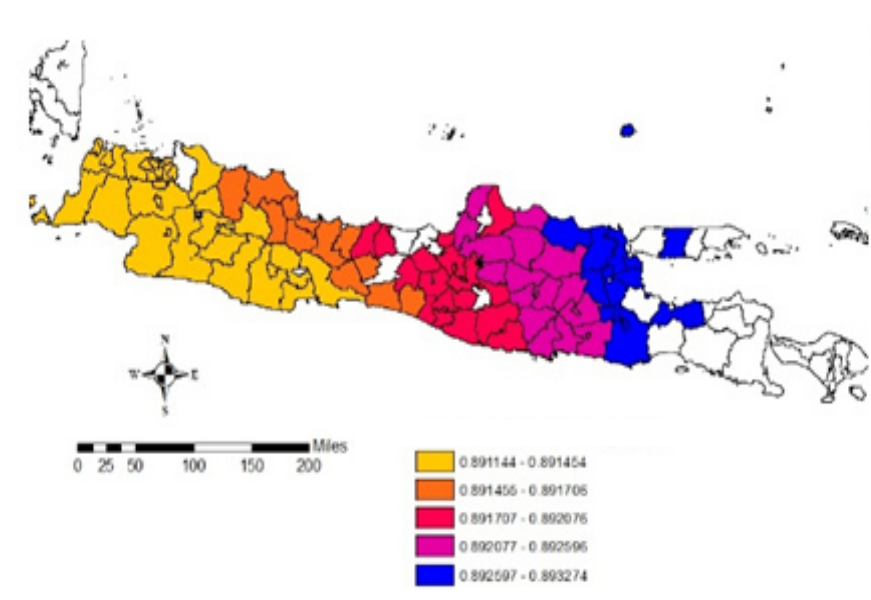

(a)

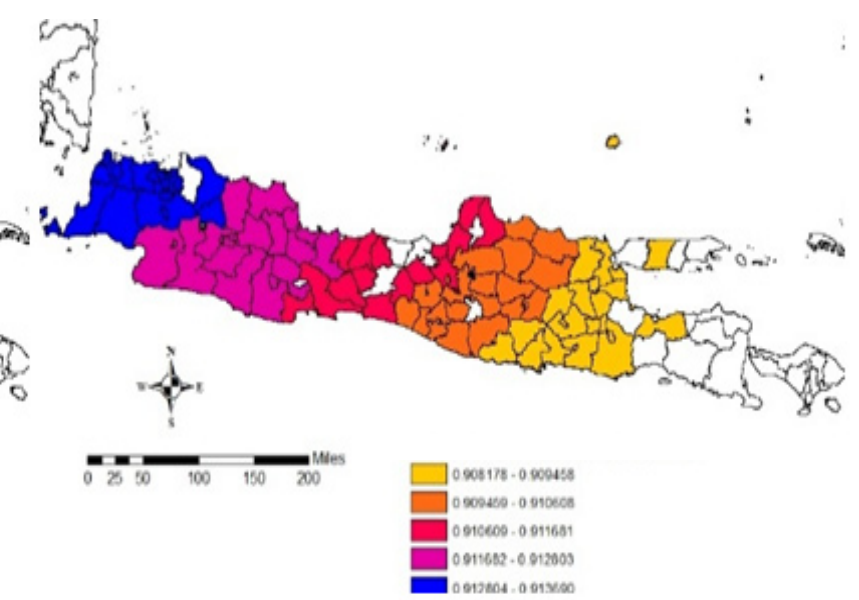

(b)

Figure 5. Parameter estimates of red chili GWR model: wholesale price (a) April, (b) September 


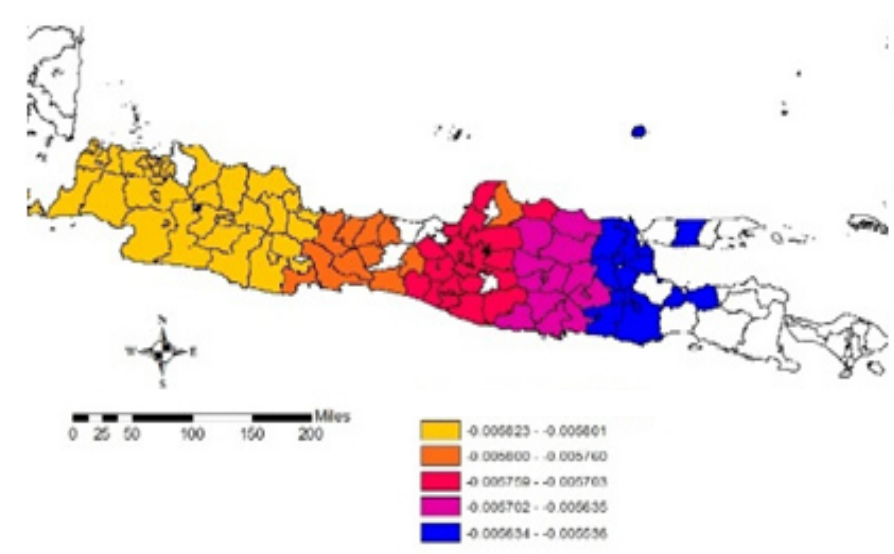

(a)

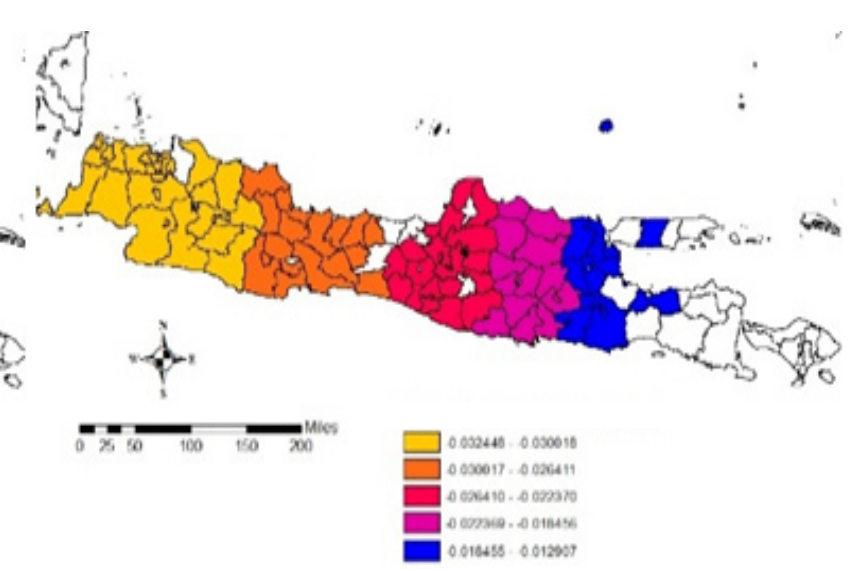

(b)

Figure 6. Parameter estimates of red chili GWR model: production (a) April, (b) September

However, the price at the farm level is depressed, so the price of GKP (producer price) negatively correlates with retail prices. Excess supply caused GKP prices to experience pressure to the lowest price level. A decline in producer prices was not transmitted to the consumer level directly or asymmetrically (Varela et al. 2012). The pressure on red chili producer price was greater than that of rice with the coefficient value between -0.1794 and 0.1897 in Java. Therefore, stabilising producer prices during the harvest season was a great challenge since the plummeting price in this period became a recurring phenomenon every year.

Red chili producer prices declined because the market could not absorb the excess supply in April. Producer price transmission is very slow on retail prices so the April production coefficient is smaller than September. The value of the September production coefficient in East Java is smaller and even positive on the east coast. This is under the research of White et al (2007) which states that $90 \%$ of the production of this area flows to wholesalers located in Jakarta so that local supply decreases and results in an increase in the retail price of red chili. Wholesalers obtain supplies in very large quantities because they have capital ownership to determine the price of red chili (Farid and Subekti, 2012). In addition, wholesalers already have a strong partnership network which is a large component of farming costs. According to Saidah et al. (2016), the structure of transaction costs on red chili farming consists of information search costs, implementation costs, trading partner search costs, and negotiation costs. The highest component of transaction costs is the cost of finding a trading partner by $25.1 \%$ and the lowest transaction cost was the cost of finding a trading partner by $7.8 \%$.
The amount of demand (consumption) had a positive effect on retail prices. The smallest coefficient of rice consumption occurred in Banten and West Java at $0.0089-0.0091$, followed by Central Java at 0.0091 0.0093 , and the largest occurred in East Java at 0.0097 - 0.0099. A similar condition was also observed from the coefficient value of Java red chili consumption. The lowest coefficient was in Banten, DKI Jakarta, and parts of West Java with an April consumption coefficient of $0.8231-0.8483$ and September coefficient of 0.9037 1.2176 , then followed by parts of West Java, Central Java and the highest was reported for East Java with April coefficient of $0.9156-0.9358$ and September coefficient of $1.8407-2.1877$ (Figure 7).

The global regression model, however, assumed that the parameter in all locations was similar. This assumption was different from the observed characteristic since wholesale price, production, producer price, and consumption had different influences on retail price. Therefore, the global regression model was less suitable for the analysis, which was location-dependent. Alternatively, the GWR model, which considered the spatial effect, was used for the medium rice and red chili retail price analysis in Java. This conclusion was supported by the low value of the coefficient determination (R2) and higher AIC compared to the GWR model (Table 2). The GWR analysis became more important, also considering the dependency analysis and spatial heterogeneity. The result that GWR analysis was better than the global regression model confirms the previously described theory that spatial analysis should be used, instead of the global regression model when spatial heterogeneity is observed. The better performance of the GWR model over a more global model was also reported by Kam et al. (2005), Ali et al. (2007), and Thongdara et al. (2012). 


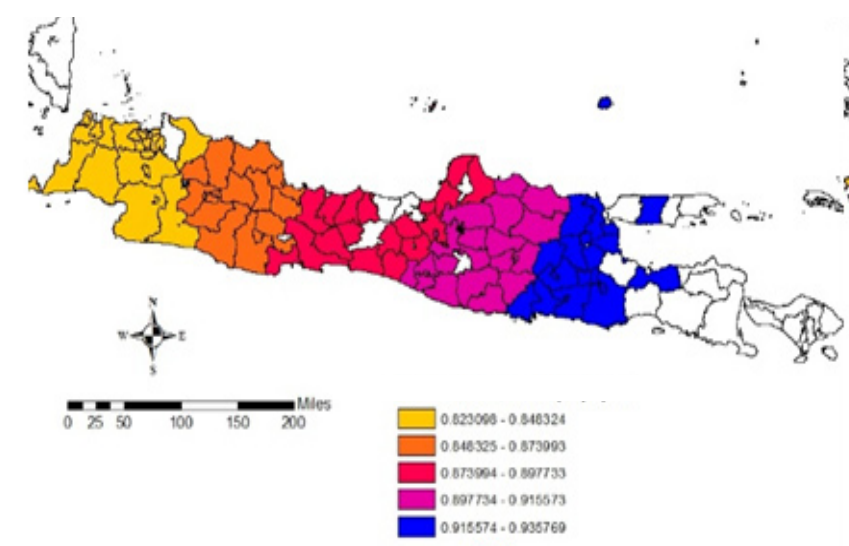

(a)

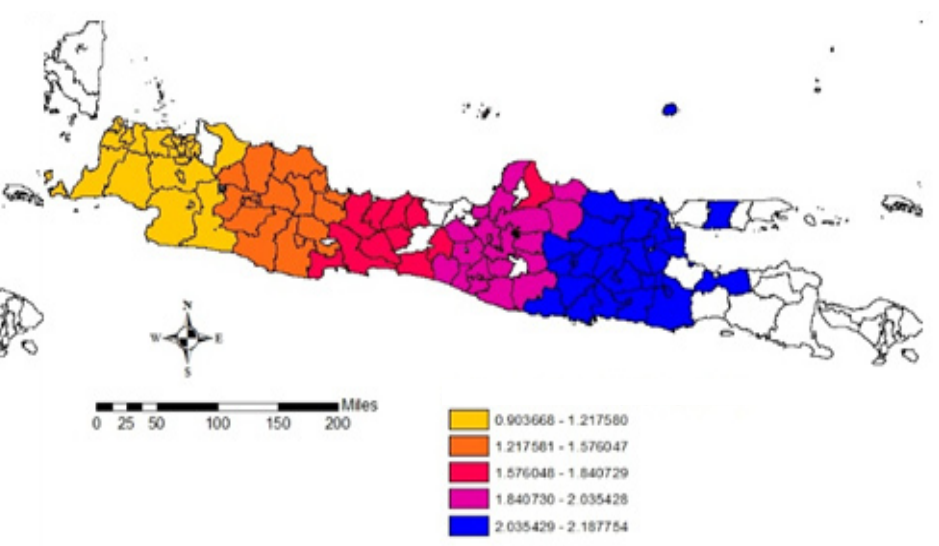

(b)

Figure 7. Parameter estimates of red chili GWR model: consumption (a) April, (b) September

\section{Managerial Implications}

The results of the GWR test showed different effects in each region and the testing period following the specific characteristics of the location. Therefore, the strengthening of supply and price stabilization of food in all regions was carried out by considering the spatial relationship of these factors. Based on our findings, an institutional food logistics institution, which carries out logistics management as National Food Hub, is needed within macro logistics.

The food hub will concentrate on aggregation, distribution and marketing, connecting producers with buyers in the supply chain (Rogoff, 2014). Food Hub is an institution that regulates the movement of commodity flows between regions. Food hub operations have been used to improve local and regional food systems, specifically by increasing market access to small and medium-scale agriculture. This means that the Food Hub carries out food production and distribution management functions to ensure the continuity of even supply and provides adequate economic incentives for all actors, including farmers.

The strengthening of food logistics institution is carried out by considering aspects of production, distribution and institutional logistics, as follows: (1) production aspect related to the ability to provide supplies originating from local production. Increasing production through increased productivity and planting area in the regions will strengthen the national and regional food logistics system, especially in deficit areas. (2) Distribution aspect is related to smoothing the distribution flow of goods from surplus to deficit areas. (3) The institutional logistics aspect (Food
Hub) is the executor of macro logistic service, the government instrument in implementing supply and price stabilization policies throughout Indonesia.

\section{CONCLUSIONS AND RECOMMENDATIONS}

\section{Conclusions}

Market integration analysis models and appropriate food prices are needed to formulate effective policies in stabilizing food supply and prices. However, the pre-cointegration and cointegration models that have been widely used so far have not been able to capture the interrelationships between regions based on the characteristics of location-specific factors. So far, the model is only represented by a few markets for all regions. In addition, the factors that affect prices and their relationship to other markets cannot be known. Factor analysis using global regression is unsuitable for site-specific analysis in each district/city, so this study uses the Geographically Weighted Regression (GWR) model. The results of the GWR test show different effects in each area and the test period according to the specific characteristics of the location. Some important points in this research are: (1) The GWR model is better than OLS, characterized by larger R2 values and smaller AIC values. (2) Wholesale prices have the most influence on the retail price of medium rice and red chili both during the harvest and non-harvest periods. (3) The harvest pattern causes the effect of production and producer prices on retail prices for the harvest and non-harvest periods to be different. The distribution between regions to maintain supply stability and food price disparities between regions. 


\section{Recommendations}

Policymaking should consider local aspects or spatial approaches that can provide a more accurate picture so that policies can be implemented more focused and on target. This implementation is carried out by the food logistics agency as an extension of the government. For this reason, it is necessary to immediately formulate a grand design for the management of national food logistics with the support of the following policies:

1. Increased production through expansion of new planting areas and opening of new planting areas, especially in deficit areas, superior seeds, and equal distribution of planting periods supported by the provision of facilities for agro-climate modification.

2. Provision of post-harvest technology including storage and processing to extend shelf life such as Controlled Atmosphere Storage (CAS), processing of dry chilies, and other processed chilies.

\section{REFERENCES}

Adenegan KO. 2012. Spatial price analysis of tomatoes in Nigeria. International Journal Manage Market 5(2):31-38.

Adytia T. 2016. Analisis faktor - faktor yang mempengaruhi volatilitas harga beras di Indonesia [tesis]. Bogor: Sekolah Program Pascasarjana, Institut Pertanian Bogor.

AliK,PartridgeMD,OlfertMR.2007.Cangeographically weight regressions improve regional analysis and policymaking?. International Regional Science Review 30(3): 300-329. https://doi. org/10.1177/0160017607301609.

Anselin L. 1988. Spatial Econometrics: Methods and Models. Belanda: Netherlands Kluwer Academic Publ. https://doi.org/10.1007/978-94015-7799-1.

Baquedano FG, Liefert WM. 2014. Market integration and price transmission in consumer markets of developing countries. Food Policy 44:103-114. https://doi.org/10.1016/j.foodpol.2013.11.001.

Barrett CB, Li JR. 2002. Distinguishing between equilibrium and integration in the spatial price analysis. American Journal of Agricultural Economics 84:292-307. https://doi. org/10.1111/1467-8276.00298.

Bekti RD, Sutikno. 2012. Spatial durbin model to identify influential factors of diarrhea. Journal of Mathematics and Statistics 8:396-402. https:// doi.org/10.3844/jmssp.2012.396.402.

Elvina. 2016. Transmisi dan pembentukan harga cabai merah serta perilaku pasar antar lembaga pemasaran cabai merah di Indonesia [tesis]. Bogor: Sekolah Program Pascasarjana, Institut Pertanian Bogor.

Engle RF, Granger CWJ. 1987. Co-integration and error correction: representation, estimation, and testing. Econometrica 55(2):251-276. https:// doi.org/10.2307/1913236.

Farid M, NA Subekti. 2012. Tinjauan terhadap produksi, konsumsi, distribusi dan dinamika harga cabai di Indonesia. Buletin Ilmiah Litbang Perdagangan 6(2):211-233.

Firdaus M, Gunawan I. 2012. Integration among regional vegetable markets in Indonesia. Journal of International Society for Southeast Asian Agricultural Sciences 18(2):96-106.

Fischer MM, Getis A. 2010. Handbook of Applied Spatial Analysis, Software Tools, Methods and Applications. New York: Springer. https://doi. org/10.1007/978-3-642-03647-7.

Fotheringham AS, Brunsdon C, Charlton M. 2002. Geographically Weighted Regression the Analysis of Spatially Varying Relationships. New York: John Wiley \& Sons, Ltd.

Goodwin BK, Schroeder TC. 1991. Cointegration test and spatial price linkage in regional cattle markes. American Journal of Agricultural Economics 73(2):452-464. https://doi. org/10.2307/1242730.

Gujarati DN. 2010. Basic Econometrics. New York: Mc Graw-hill Companies

Hidayanto HW. 2014. Analisis faktor penentu integrasi pasar beras di Indonesia [tesis]. Bogor: Sekolah Program Pascasarjana, Institut Pertanian Bogor.

Hill RC, Griffiths WE, Lim, GC. 2011. Principles of Econometrics. USA: John Wiley \& Sons Inc.

Irawan B. 2007. Fluktuasi harga, transmisi harga dan marjin pemasaran sayuran dan buah. Analisis Kebijakan Pertanian 5(4):358-373.

Kam SP, Hossain M, Bose ML, Villano LS. 2005. Spatial patterns of rural poverty and their relationship with welfare-influencing factors in Bangladesh. Food Policy 30(5):551-567. https:// doi.org/10.1016/j.foodpol.2005.10.001.

Muta'ali. 2012. Daya Dukung Lingkungan Untuk Perencanaan Pengembangan Wilayah. Yogyakarta: Badan Penerbit Fakultas Geografi, Universitas Gadjah Mada. 
NegassaA, Meyers R, Gabre-Mahdin E.2003.Analyzing grain market efficiency in developing countries: review of existing methods and extensions of the parity bound model. International Food Policy Research Institute.

Pravitasari AE, Saizen I, Tsutsumida N, Rustiadi E, Pribadi DO. 2015. Local spatially dependent driving forces of urban expansion in an emerging Asian megacity: The case of greater Jakarta (Jabodetabek). International Journal of Sustainable Development 8(1):108-119. https:// doi.org/10.5539/jsd.v8n1p108.

Ridwan, MHA, Karlina, I, Yanfitri. 2012. Kajian komoditas pangan strategis: Faktor determinasi variasi harga antardaerah. World Bank Working Paper.

Rogoff J. 2014. Improving systems of distribution and logistics for regional food hubs. https://dusp.mit. edu/sites/dusp.mit.edu/files/attachments/project/ Food\%20Hub\%20Report\%2010_12_14.pdf.

Sanogo I, Amadou MM. 2010. Rice market integration and food security in Nepal: The role of cross-border trade with India. Food Policy 35(4):312-322.https://doi.org/10.1016/j. foodpol.2010.03.002.

Saidah Z et al. 2019. Transaction cost analysis on revenues and profits of red chili farming. Jurnal Manajemen and Agribisnis 16(1):66-76. https:// doi.org/10.17358/jma.16.1.66.
Siddique MAB, Raha SK, Alam MS. 2008. Market integration: an application of co-integration and error correction model to rice markets in Bangladesh. The Agriculturists 6(1\&2):90-98. https://doi.org/10.3329/agric.v6i1.5219.

Susilowati SH. 2017. Perdagangan antarpulau beras di provinsi Sulawesi Selatan. Analisis Kebijakan Pertanian 15(1):19-41.https://doi.org/10.21082/ akp.v15n1.2017.19-41.

Thongdara R, Samarakoon L, Shrestha RP, Ranamukhaarachchi SL. 2012. Using GIS and spatial statistics to target poverty and improve poverty alleviation programs: A case study in northeast Thailand. Applied Spatial Analysis and Policy 5(2):157-182. https://doi.org/10.1007/ s12061-011-9066-8.

Udoh EJ, Sunday BA. 2007. Estimating exportable tree crop relative price variability and inflation movement under different policy regimes in Nigeria. European Journal of Social Sciences 5(2):17-26.

Varela G, Aldaz-Carroll E, Iacovone L. 2013. Determinants of market integration and price transmission in Indonesia. Journal of Southeast Asian Economies 30(1):19-44. https://doi. org/10.1355/ae30-1b.

White B, Phillip M, Natawidjaja R, Morgan W. 2007. Vegetable Value Chains in Eastern Indonesia-a Focus on Chilli. Canberra: Australian Centre for International Agriculture Research. 